\title{
Hubungan Kadar Plasma Chemerin dengan Homeostasis Model Assessment Insulin Resistance pada Remaja Obesitas
}

\author{
Silvy Dioni, Eka Agustia Rini,* Eti Yerizel** \\ ${ }^{*}$ Departemen Ilmu Kesehatan Anak Fakultas kedokteran Universitas Andalas/RSUP dr. M. Djamil, Padang \\ **Pasca sarjana Ilmu Biomedik Fakultas Kedokteran Universitas Andalas
}

\begin{abstract}
Latar belakang. Obesitas pada anak berhubungan dengan meningkatnya risiko sindrom metabolik, seperti resistensi insulin. HOMAIR merupakan marker yang sering digunakan untuk menilai resistensi insulin. Chemerin merupakan protein $18 \mathrm{kDa}$ yang dihasilkan jaringan adiposa, berfungsi sebagai chemoatractant memegang peran penting berkontribusi terhadap perkembangan inflamasi dan resistensi insulin.

Tujuan. Untuk mengetahui hubungan kadar chemerin dengan HOMA-IR pada remaja obesitas.

Metode. Penelitian ini merupakan penelitian cross sectional yang dilakukan pada 3 sekolah menengah umum (SMU) di kota Padang. Jumlah sampel berjumlah 28 remaja obesitas dan 28 remaja dengan IMT normal. Obesitas ditentukan berdasarkan nilai IMT, HOMA-IR dihitung berdasarkan rumus yang menggunakan nilai glukosa dan insulin puasa. Glukosa diukur dengan metode glucose hexokinase fotometrik, insulin diperiksa dengan metode chemiluminessence immunoassay dan kadar plasma chemerin dengan metode ELISA. Data dianalisis dengan sistem komputerisasi dengan uji korelasi.

Hasil. Kadar plasma chemerin lebih tinggi pada kelompok obesitas dibandingkan kontrol 121,52 (SD 2,09) ng/ml vs 97,23(SD 2,41) ng/ml, p: 0,001 dan pada kelompok obesitas dengan resistensi insulin dibandingkan non resistensi insulin 133,1(SD 19,24) vs 115,09 (SD 19,52), $\mathrm{p}=0,001$. Terdapat hubungan lemah kadar chemerin dengan nilai HOMA-IR pada obesitas

$(\mathrm{r}=0,382 ; \mathrm{p}=0,045)$ dan hubungan lemah kadar chemerin dengan nilai HOMA-IR pada obesitas resistensi insulin ( $r=0,297 ; \mathrm{p}=0,405)$. Kesimpulan. Terdapat hubungan lemah kadar chemerin dengan nilai HOMA-IR pada remaja obesitas, dan hubungan lemah kadar chemerin dengan nilai HOMA-IR pada obesitas resistensi insulin. Sari Pediatri 2020;22(1):24-9
\end{abstract}

Kata kunci. remaja obesitas, resistensi insulin, plasma chemerin

\section{Relationship of Chemerin Plasma Levels with Homeostasis Model for Insulin Resistance Assessment in Obesity Adolescent}

Silvy Dioni, Eka Agustia Rini, ${ }^{*}$ Eti Yerizel**

Background. Childhood obesity associated with an increased risk for metabolic syndromes, such as insulin resistance. Homeostatic model assessment insulin resistance (HOMA-IR) is a chemical marker widely used for insulin resistance. Chemerin is a $18 \mathrm{kDa}$ protein produced by adipose tissue, function as chemoattractant plays an important role contributing to the development of inflammation and insulin resistance.

Objective. To determine assosiation chemerin level and HOMA-IR in obese adolescent.

Methods. This was a cross-sectional study and conducted in three senior high schools in Padang. Twenty-eight obese adolescents and 28 control were enrolled in the study. The age of the subjects ranged from 14-18 years. Obesity criteria were measure based on body mass index (BMI). Fasting serum glucose level measured by glucose hexokinase photometric method and serum insulin was measured by chemiluminessence immunoassay method. Plasma chemerin was measured with enzyme-linked immunosorbent assay (ELISA). The insulin resistance index was estimated from fasting serum insulin and glucose level using the formula. Data were analyzed using correlation test, and t-test, $\mathrm{p}<0,05$ was significant.

Result. The plasma chemerin level was higher in the obese than in the control group 121,52 (SD 2,09) ng/ml vs 97,23 (SD 2,41) $\mathrm{ng} / \mathrm{ml}, \mathrm{p}: 0,001$, and the insulin resistance group had higher plasma chemerin level than non resistance group 133,1(SD 19,24) vs 115,09 (SD 19,52), p: 0,027. There is a weak correlation with the value chemerin levels HOMA-IR in obesity $(\mathrm{r}=0.382 ; \mathrm{p}=0.045)$ and weak correlation with value chemerin levels HOMA-IR in obese insulin resistance $(r=0.297 ; \mathrm{p}=0.405)$.

Conclusion. There is a weak correlation with the value chemerin levels HOMA-IR in obesity and insulin resistance. Sari Pediatri 2020;22(1):24-9

Keywords: obese adolescents, insulin resistance, plasma chemerin

Alamat korespondensi: Silvy Dioni. Departemen Ilmu Kesehatan Anak FK-UNAND/RSUP dr. M. Djamil Jl. Perintis Kemerdekaan. Padang, Sumatera Barat. Email: silvy.dioni@yahoo.com 
Silvy Dioni dkk: Hubungan kadar plasma chemerin dengan homeostasis model assessment insulin resistance pada remaja obesitas

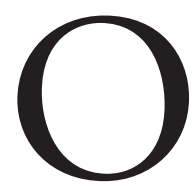

besitas merupakan suatu keadaan patologis yang ditandai oleh penumpukan lemak berlebihan secara menyeluruh di bawah kulit dan jaringan lain di dalam tubuh. ${ }^{1}$ Obesitas saat ini sudah merupakan epidemi global. ${ }^{2}$ Data dari National Health and Nutrition Examination Survey (NHANES) tahun 2000 menyebutkan obesitas pada anak $20,6 \%$ dan remaja $30,4 \% .{ }^{3}$ Di Indonesia, khususnya provinsi Sumatera Barat, berdasarkan data Riset Kesehatan Dasar (Riskesdas) tahun 2013, sama dengan prevalensi nasional. ${ }^{4,5}$

Anak obesitas berisiko untuk menjadi obesitas saat dewasa sampai $80 \%$. ${ }^{6,7}$ Dampak negatif obesitas adalah terjadinya resistensi insulin, Beberapa penelitian menunjukkan bahwa $52 \%$ sampai $72 \%$ anak overweight dan obesitas mengalami resistensi insulin. ${ }^{8,9}$ Pulungan $\mathrm{dkk}^{10}$ melaporkan 38\% remaja obesitas usia 12-15 tahun mengalami resistensi insulin. Lestari ${ }^{11}$ melaporkan resistensi insulin 31,6\% remaja obesitas di Kota Padang. Salah satu marker biokimia untuk menilai resistensi insulin adalah Homeostasis Model of Assessment IR (HOMA-IR), yang dikembangkan oleh Matthews $\mathrm{dkk}^{12}$ telah digunakan secara luas untuk memperkirakan resistensi insulin dalam penelitian.

Mekanisme yang menghubungkan obesitas dengan resistensi insulin yaitu terjadinya inflamasi kronik derajat rendah pada obesitas, ditandai oleh infiltrasi makrofag dan sekresi adipokin. Adipokin juga berperan penting pada regulasi lemak sistemik dan metabolisme glukosa di otak, hepar dan otot. Sekresi adipokin, di antaranya leptin Tumor Necrosis Factor- $\alpha$ (TNF- $\alpha$ ), interleukin 6 (IL-6), dan chemokine ( $C$-C ligand 2) C-CL2, adiponektin, resistin, omentin, vaspin, vistafin, dan chemerin. ${ }^{13-15}$

Chemerin berkontribusi terhadap perkembangan inflamasi dan resistensi insulin. Chemerin berinteraksi langsung dengan reseptor (chemokine-like receptor), diaktifkan melalui pembelahan proteolitik, berikatan dengan reseptor, dan kemudian akan merekrut sel imun ke dalam lesi. ${ }^{16,17}$ Takahashi $\mathrm{dkk}^{17}$ menjelaskan chemerin berhubungan dengan resistensi insulin dan obesitas. Bozaoglu $\mathrm{dkk}^{18}$ meneliti individu dewasa dengan kelebihan berat badan terdapat peningkatan kadar serum chemerin, yang berkorelasi positif dengan indeks massa tubuh (IMT), kadar glukosa, tirgliserida. Sledzinski $\mathrm{dkk}^{19}$ menemukan kadar chemerin serum lebih tinggi pada anak obesitas dibandingkan kontrol, berkorelasi positif dengan IMT. Selain itu, chemerin berkolerasi positif dengan $C$-reactive protein (CRP).
Stejskal $\mathrm{dkk}^{20}$ menemukan kadar serum chemerin meningkat pada subjek sindrom metabolik. Chemerin berhubungan dengan kadar glukosa, high density lipoprotein (HDL), dan dapat dijadikan sebagai marker sindrom metabolik.

Sementara penelitian tentang hubungan kadar plasma chemerin dengan nilai HOMA-IR sebagai penanda resistensi insulin belum pernah dilakukan di Indonesia, apalagi pada populasi anak atau remaja obesitas. Berdasarkan latar belakang di atas, maka penulis tertarik untuk melakukan penelitian dengan judul hubungan kadar plasma chemerin dengan HOMA-IR pada remaja obesitas di kota Padang.

\section{Metode}

Penelitian ini adalah penelitian cross sectional study Penelitian dilakukan di beberapa Sekolah Menengah Umum (SMU) di kota Padang dan laboratorium klinik Prodia Padang pada Januari sampai Oktober 2015.

Populasi penelitian ini adalah siswa beberapa SMU di kota Padang yang mengalami obesitas yang memenuhi kriteria inklusi dan ekslusi. Jumlah subjek penelitian 48 orang dan dilakukan pemeriksaan kadar chemerin dengan metode ELISA. dilakukan dilaboratorium Prodia.

Kriteria inklusi adalah remaja obesitas usia 14-18 tahun yang bersedia untuk mengikuti penelitian.

Kriteria eksklusi adalah anak mengalami sakit saat penelitian dilakukan sehingga tidak memungkinkan berpuasa dan menjalani prosedur pemeriksaan, sedang mengonsumsi obat yang dapat memengaruhi metabolisme glukosa (seperti biguanid, insulin, dexametason), mengonsumsi obat penurun kadar lemak darah, seperti statin dan fibrat.

Kadar chemerin diperiksa dengan metode Enzyme Linked Immunosorbent assay (ELISA) secara invitro, menggunakan human chemerin adalah produk $R \circlearrowleft D$ systems, USA.

\section{Hasil}

Telah dilakukan penelitian terhadap remaja obesitas pada bulan Januari 2015 - September 2015 melalui skrining obesitas terhadap 1200 orang siswa pada 3 SMU di kota Padang didapatkan remaja obesitas sebanyak 135 (11,25\%) orang. Karakteristik subjek 
penelitian tertera pada Tabel 1 .

Mayoritas kelompok obesitas adalah perempuan $85,72 \%$, sedangkan laki-laki 14,28\%. Pada kelompok obesitas, riwayat keluarga obesitas dan non obesitas 15:13 (hampir sama). Kelompok obesitas sebagian besar tekanan darah > persentil 95 .

Rerata kadar insulin dan HOMA-IR kelompok obesitas lebih tinggi dibandingkan kelompok non obesitas dan bermakna secara statistik, sedangkan nilai median kadar glukosa darah puasa kedua kelompok tidak terdapat perbedaan bermakna.

Pada remaja obesitas ditemukan 10 orang $(35,7 \%)$ dengan resistensi insulin, dan terbanyak remaja perempuan. Karakteristik masing-masing kelompok tertera pada Tabel 1.

Pada Tabel 2, rerata kadar chemerin kelompok obesitas lebih tinggi dibandingkan kelompok non obesitas dan bermakna secara statistik $(\mathrm{p}<0,05)$.

Pada Tabel 3, rerata kadar chemerin kelompok resistensi insulin lebih tinggi dibandingkan kelompok non resistensi insulin dan bermakna secara statistik $(\mathrm{p}<0,05)$.

Pada Gambar 1, terdapat korelasi lemah antara kadar chemerin dengan nilai HOMA-IR remaja obesitas ( $\mathrm{r}=0,382)$, semakin tinggi kadar chemerin semakin tinggi pula nilai HOMA-IR.

Pada Gambar 2, terdapat korelasi lemah antara kadar chemerin dengan nilai HOMA-IR remaja

Tabel 1. Karakteristik dan deskripsi variabel kelompok resistensi dan non resistensi insulin

\begin{tabular}{|c|c|c|c|}
\hline Variabel & $\begin{array}{l}\text { Resistensi insulin } \\
\qquad(\mathrm{n}=10)\end{array}$ & $\begin{array}{l}\text { Non resistensi insulin } \\
\qquad(\mathrm{n}=18)\end{array}$ & Nilai $\mathrm{p}$ \\
\hline \multicolumn{4}{|l|}{ Jenis kelamin } \\
\hline Laki-laki (n)\% & $2(20)$ & $2(11,11)$ & \multirow{2}{*}{$0,452^{*}$} \\
\hline Perempuan (n)\% & $8(80)$ & $16(88,89)$ & \\
\hline \multicolumn{4}{|l|}{ Usia } \\
\hline Median (min-maks) & $16,5(15-18)$ & $16(15-18)$ & $0,710^{* * *}$ \\
\hline \multicolumn{4}{|l|}{ Riwayat Keluarga Obesitas } \\
\hline Ada (n) \% & $7(70)$ & $8(44,44)$ & \multirow[t]{2}{*}{$0,184^{*}$} \\
\hline Tidak ada (n) \% & $3(30)$ & $10(55,56)$ & \\
\hline \multicolumn{4}{|l|}{ IMT } \\
\hline Rerata $\pm \mathrm{SD} \mathrm{kg} / \mathrm{m}^{2}$ & $34,26 \pm 4,49$ & $31,10 \pm 3,39$ & $0,061^{* *}$ \\
\hline \multicolumn{4}{|l|}{ Tekanan darah } \\
\hline Persentil < $90(\%)$ & $2(20)$ & $8(44,44)$ & \multirow{3}{*}{$0,001^{*}$} \\
\hline $90<$ Persentil > $95(\%)$ & $3(30)$ & $4(22,22)$ & \\
\hline Persentil > $95(\%)$ & $5(50)$ & $6(33,33)$ & \\
\hline \multicolumn{4}{|l|}{ Glukosa darah puasa } \\
\hline Median(min-maks) mg/dl & $85(71-94)$ & 77 (69-99) & $0,064^{* * *}$ \\
\hline \multicolumn{4}{|l|}{ Insulin } \\
\hline Rerata $\pm \mathrm{SD}(\mu \mathrm{IU} / \mathrm{mL})$ & $20,38 \pm 5,6$ & $8,48 \pm 3,27$ & $0,001^{* *}$ \\
\hline \multicolumn{4}{|l|}{ HOMA-IR } \\
\hline Median (min-maks) & $4,06(3,35-7,10)$ & $1,39(0,74-2,83)$ & $0,001^{* * *}$ \\
\hline
\end{tabular}

Tabel 2. Perbedaan kadar plasma chemerin kelompok obesitas dan non obesitas serta resistensi insulin dan non resistensi insulin

\begin{tabular}{|c|c|c|c|}
\hline \multirow[b]{2}{*}{ Kelompok } & Variabel & $\begin{array}{l}\text { Kadar plasma chemerin } \\
(\mathrm{ng} / \mathrm{mL})\end{array}$ & \multirow[t]{2}{*}{ Nilai p } \\
\hline & & Rerata $\pm S D$ & \\
\hline Obesitas & & $121,52 \pm 2,09$ & \multirow{2}{*}{$0,001^{* *}$} \\
\hline Non obesitas & & $97,23 \pm 2,41$ & \\
\hline Resistensi & & $133, \pm 19,24$ & \multirow{2}{*}{$0,027^{*}$} \\
\hline Non resistensi & & $115,09 \pm 19,52$ & \\
\hline
\end{tabular}


Silvy Dioni dkk: Hubungan kadar plasma chemerin dengan homeostasis model assessment insulin resistance pada remaja obesitas

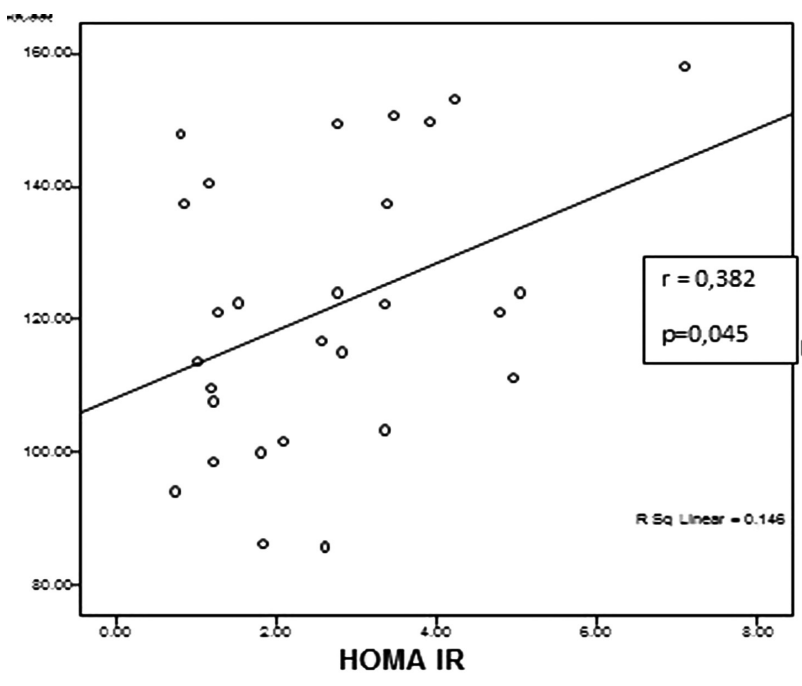

Gambar 1. Hubungan kadar chemerin dengan nilai HOMA-IR pada remaja obesitas

obesitas resistensi insulin $(\mathrm{r}=0,297)$, semakin tinggi kadar chemerin semakin tinggi pula nilai HOMA-IR.

\section{Pembahasan}

Pada penelitian ini terdapat korelasi lemah kadar chemerin dengan HOMA- IR pada obesitas dan terdapat korelasi lemah antara kadar chemerin dengan nilai HOMA-IR remaja obesitas resistensi insulin. Sejalan dengan Penelitian Florinela $\mathrm{dkk}^{21}$ pada 32 pasien sindrom metabolik didapatkan kadar chemerin serum meningkat, sedangkan omentin-1 menurun dibandingkan kontrol. Chemerin berkolerasi dengan insulin, HOMA-IR, LDL, tetapi berkolerasi negatif dengan total oxidative respon. Omentin-1 berkolerasi negatif dengan TNF alfa dan kolesterol. Hal ini disimpulkan bahwa jaringan adiposa dianggap sebagai organ endokrin aktif yang menghasilkan berbagai jumlah adipokin yang memicu keadaan inflamasi kronik, stres oksidatif, dan resistensi insulin sehingga meningkatkan komplikasi metabolik. Chemerin dapat memainkan peran dalam resistensi insulin dan stres oksidatif. Penelitian Florinela $\mathrm{dkk}^{21}$ juga mengamati bahwa kontributor independen utama peningkatan chemerin adalah HOMA-IR.

Penelitian lain Sell $\mathrm{dkk}^{24}$ melaporkan hubungan chemerin dan sensitivitas insulin pada 60 pasien perempuan obesitas yang menjalani operasi bariatrik,

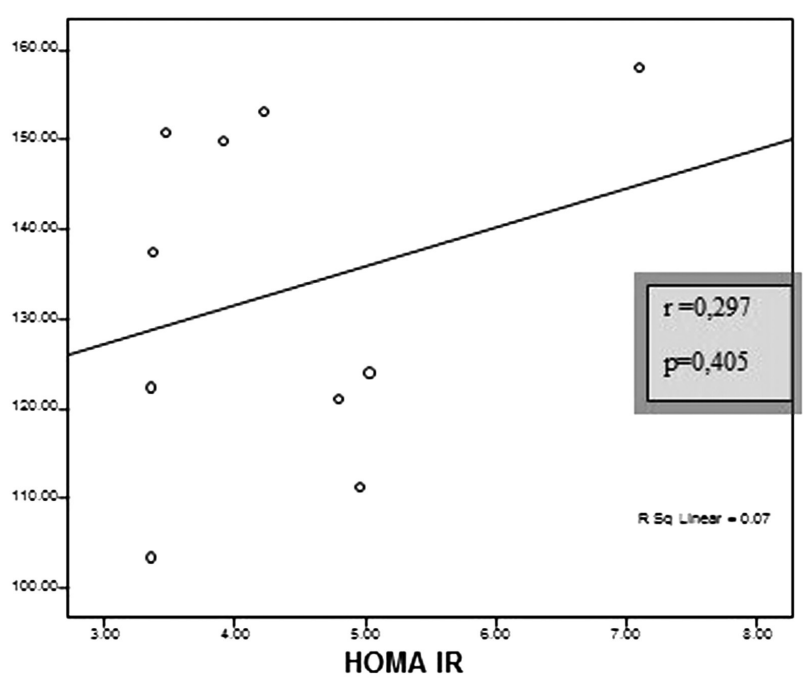

Gambar 2. Hubungan kadar chemerin dengan nilai HOMA-IR pada remaja obesitas resistensi insulin

efektif menurunkan berat badan dan massa lemak dan secara bermakna terdapat perbaikan parameter metabolik, di antaranya glukosa, insulin, HOMAIR, CRP, dan adipokin diantaranya leptin, IL-10 dan chemerin. Dilakukan pemeriksaan chemerin sebelum operasi $(354 \pm 18 \mathrm{ng} / \mathrm{ml})$ dan 3, 6, 12 bulan setelah operasi didapatkan chemerin menurun dan terdapat perbaikan sensitivitas insulin. Sell dkk juga melaporkan korelasi antara indeks resistensi insulin (HOMA-IR) dan chemerin, terdapat hubungan antara chemerin yang beredar dalam sirkulasi dengan jumlah makrofag dalam jaringan adiposa omentum. Hal ini dianggap bahwa adiposit dan preadiposit berkontribusi pada kadar chemerin yang beredar.

Hal ini sejalan dengan penelitian Sledzinski dkk ${ }^{19}$ yang melaporkan bahwa BMI merupakan prediktor utama konsentrasi serum chemerin. Dapat disimpulkan bahwa kadar chemerin dapat memengaruhi homeostasis glukosa dan menyebabkan perkembangan resistensi insulin. ${ }^{18}$ Kadar chemerin serum meningkat pada manusia dan tikus menunjukkan bahwa chemerin mungkin juga memengaruhi disregulasi metabolisme glukosa yang terjadi dengan obesitas, melalui induksi resistensi insulin terutama di otot rangka. Penelitian terbaru menunjukkan bahwa chemerin menginduksi resistensi insulin di otot rangka dengan menghambat insulin-stimulated Akt1 fosforilasi dan mengaktifkan kinase 5 AMP-activated protein (AMPK), glycogen synthase kinase 3 phosphorylation, dan uptake glukosa. ${ }^{22}$ 
Silvy Dioni dkk: Hubungan kadar plasma chemerin dengan homeostasis model assessment insulin resistance pada remaja obesitas

Beberapa peneliti menyimpulkan bahwa peningkatan kadar chemerin serum berkaitan dengan jumlah total persentase lemak tubuh pada pasien tanpa sebelumnya terdapat riwayat atau bukti penyakit kardiovaskular, diabetes, hipertensi atau dislipidemia. Di lain pihak menurut weigert $\mathrm{dkk}$ menganalisis kelompok obesitas diabetes tipe 2 peningkatan kadar chemerin lebih berhubungan dengan inflamasi dibandingkan BMI sehingga menunjukkan chemerin yang mungkin lebih sebagai marker inflamasi dibandingkan obesitas. ${ }^{23}$

Penelitian ini menunjukkan bahwa chemerin dapat sebagai alat diagnostik untuk obesitas dan komplikasi pada anak. Namun, keterbatasan penelitian ini membatasi penentuan hubungan sebab akibat, dan ukuran sampel yang sedikit. Studi longitudinal tambahan dengan ukuran sampel yang lebih besar diperlukan untuk mengonfirmasi temuan ini. Selain itu, penelitian ini mempunyai keterbatasan, antara lain, obesitas dinilai dengan IMT bukan dengan pengukuran lemak tubuh menggunakan scanning atau MRI yang memiliki keakuratan tinggi dalam menilai distribusi lemak tubuh. Keterbatasan lain pada penelitian ini adalah tidak dilakukan pemeriksaan profil lipid yang berguna untuk menentukan kriteria sindrom metabolik.

\section{Kesimpulan}

Berdasarkan hasil penelitian yang dilakukan maka dapat diambil beberapa kesimpulan diantaranya, terdapat perbedaan yang signifikan kadar plasma chemerin pada kelompok obesitas dibandingkan non obesitas. Terdapat perbedaan yang signifikan kadar plasma chemerin pada kelompok obesitas dengan resistensi insulin dibandingkan obesitas non resistensi insulin. Terdapat korelasi lemah chemerin dengan nilai HOMA-IR pada kelompok obesitas. Terdapat korelasi lemah chemerin dengan nilai HOMA-IR pada kelompok obesitas resistensi insulin.

\section{Daftar pustaka}

1. Barness LA. Obesity. Dalam: Behrman RE, Kliegman RM, Arvin AM, penyunting. Nelson texbook of pediatrics. Edisi ke-15. Philadelphia: Saunder;1996.h.169-72.

2. WHO. Obesity: preventing and managing the global epidemic,
WHO Technical Report Series. Geneva: WHO; 2000.

3. WHO. Population based strategies for prevention of childhood obesity : theory and practice. Report of a WHO forum and technical meeting. Geneva: WHO; 2010.

4. Hassink GS, penyunting. Epidemiology of Childhood obesity. A clinical guide to pediatric weight management and obesity. Edisi pertama. Lippincott Williams \& Wilkins;2007.h.8-17.

5. Kementrian Kesehatan Republik Indonesia. Riset Kesehatan Dasar (Riskesdas) 2013. Jakarta: Kemkes RI, 2013.

6. Aycan Z. Obesity in childhood: definition and epidemiology. J Clin Res Ped Endo 2009;1:44-53.

7. Lioyd LJ, Langley-Evans SC, McMullen S. Childhood obesity and risk of the adult metabolic syndrome: a systematic review. Int J Obesity 2012;36:1-11.

8. Druet D, Dabbas M, Baltakse V, Payen C, Jouret B, Baud C, $\mathrm{dkk}$. Insulin resistance and the metabolic syndrome in obese French children. Clin Endocrinol 2006;64:672-8.

9. Lee JM, Okumura MJ, Davis MM, Herman WH, Gurney JG. Prevalence and determinants of insulin resistance among U.S. adolescents: a population-based study. Diabetes Care 2006;29:2427-32.

10. Pulungan BA, Puspitadewi A, Sekartini R. Prevalence of insulin resistance in obese adolescents. Paediatr Indonesiana 2013;53:167-72.

11. Lestari R. Hubungan nilai homeostasis model assesment of insulin resistance dengan acanthosis nigricans dan tekanan darah pada remaja obesitas di Kota Padang. Padang: Andalas; 2011.

12. Keskin M, Kurtoglu S, Kendirci M, Atabek ME, Cevat. Homeostasis model assesment is more reliable than fasting glukose/insulin ratio and quantitative insulin sensitivity check index for assessing insulin resistance among obese children and adolescents. Pediatric 2005;115:500-3.

13. Viner RM, Segal TY, Lichtarowicz-Krynska E, Hidmarsh P. Prevalence of the insulin resistance syndrome in obesity. Arch Dis Child 2005;90:10-4.

14. Wellen KE, Hotamisligil GS. Obesity -induced inflammatory changes in adipose tissue. J Clin Invest 2003;112:1785-88.

15. Bluher M. Clinical relevance of adipokines. Diabetes Metab J 2012;36:317-37.

16. Goralski, KB, McCarthy TC, Hanniman EA, Zabel BA, Butcher EC, Parlee SD, dkk. Chemerin, a novel adipokine that regulates adipogenesis and adipocyte metabolism. J Biol Chem 2007;282: 28175-88.

17. Takahashi M, Takahashi Y, Takahashi K, Zolotaryov FN, Hong KS, Kitazawa R. dkk. Chemerin enhances insulin signaling and potentiates insulin-stimulated glucose uptake in 3T3-L1 adipocytes. FEBS Lett 2008; 582:573-8.

18. Bozaoglu K, Bolton K, McMillan J, Zimmet P, Jowett J, Collier $\mathrm{G}$, dkk. Chemerin is a novel adipokine associated with obesity 
and metabolic syndrome. Endocrinology 2007;148:4687-94.

19. Sledzinski T, Korczynskal J, Hallmanl. A. The increased of serum chemerin concentration is mainly associated with the increase of BMI in obese, non-diabetic subjects. 2012;56-8.

20. Stejskal D, Karpisek M, Hanulova Z, Svestak M. Chemerin is an independent marker of the metabolic syndrome in a Caucasian population--a pilot study. Biomed Pap Med 2008;152: 217-21.

21. Florinela A, Catoi, Suciu S, Parvu AE, Copaescu C, Galea RF, dkk. Increased chemerin and decreased omentin-1 levels in morbidly obese patients are correlated with insulin resistance, oxidative stress, and chronic inflammation. Clujul Medical 2014;87:19-26.
22. Sell H, Laurencikiene J, Taube A, Eckardt K, Cramer A.Chemerin is a novel adipocyte-derived factor inducing insulin resistance in primary human skeletal muscle cells. Diabetes 2009; 58:2731-40.

23. Landgraf, K, Friebe D, Ullirch T, Kratzsch J, Dittrich K, Herberth G, dkk. Chemerin as a mediator between obesity and vascular inflammtion in Chidren. J Clin Endocrinol Metab 2012;97:559-63.

24. Sell H, Divoux A, Poitou C, Basdevant A, Bouillot JL, Bedossa $\mathrm{P}, \mathrm{dkk}$, Chemerin correlates with markers for fatty liver in morbidly obese patients and strongly decreases after weight loss induced by bariatric surgery. J Clin Endocrinol Metab 2010;95:2892-6. 